\title{
ALFATHESIN BY CONTINUOUS INFUSION SUPPLEMENTED WITH INTERMITTENT PENTAZOCINE
}

\author{
J.P. DECHÊNE
}

IT IS THE AIM OF THIS PAPER to introduce the technique of continuous intravenous infusion of the relatively new steroid anaesthetic Alfathesin, in conjunction with intermittent pentazocine (Talwin) analgesia. We shall attempt to demonstrate the advantages of Alfathesin and of this particular method of administration.

\section{Rationale for the technique}

Alfathesin. Having been introduced to Alfathesin, a mixture of the two steroids alphaxalone and alphadolone, at the 5th World Congress of Societies of Anesthesiology in Kyoto, Japan and having had occasion to assess it in some 200 surgical procedures in ambulatory patients, we have endeavoured to find a method of administration which would obviate some of the disadvantages while yet retaining the very real advantages of Alfathesin. The drawbacks of the agent which have in the past limited its use for maintenance of anaesthesia are its short duration and the absence of analgesia. To overcome the short action we have resorted to intermittent injection, but this technique is less than satisfactory because it is difficult to maintain a stable level of anaesthesia. The advantages of Alfathesin lie in its speed of action, its low toxicity and the paucity of undesirable side effects both during anaesthesia and on recovery.

In contemplating the advisability of continuous infusion it was necessary to consider possible cumulative effects, if any. It is known from the work of British researchers ${ }^{1}$ that, following intravenous injection, the plasma concentration of the agent recedes quickly after an initial peak, the half-life of Alfathesin in plasma being seven minutes. Serum protein binding is weak, although studies in animals show an affinity to albumin and beta lipo-proteins. The distribution of the two constituents of Alfathesin is similar to other steroids and no particular affinity in distribution towards fatty tissues has been observed. The agent undergoes metabolic degradation in the liver by means of combination with glycuronic acid. Only two cases of prolonged recovery from anaesthesia in the presence of hepatic insufficiency have been described in the literature.- The lack of cumulative effect is further evident from our own observation that no reduction in successive doses of Alfathesin was possible with the intermittent injection technique which was originally used. Based on these observations we felt justified in attempting the continuous infusion technique.

Pentazocine. The absence of analgesic properties of Alfathesin made it imperative that another agent be added to provide such analgesia. This end has been achieved in Europe primarily by the use of dextromoramide (Palfium) or by

J.P. Dechêne, M.D., F.R.C.P.(C), Department of Anaesthesia, Jewish Ceneral Hospital and McGill University, Montreal. 


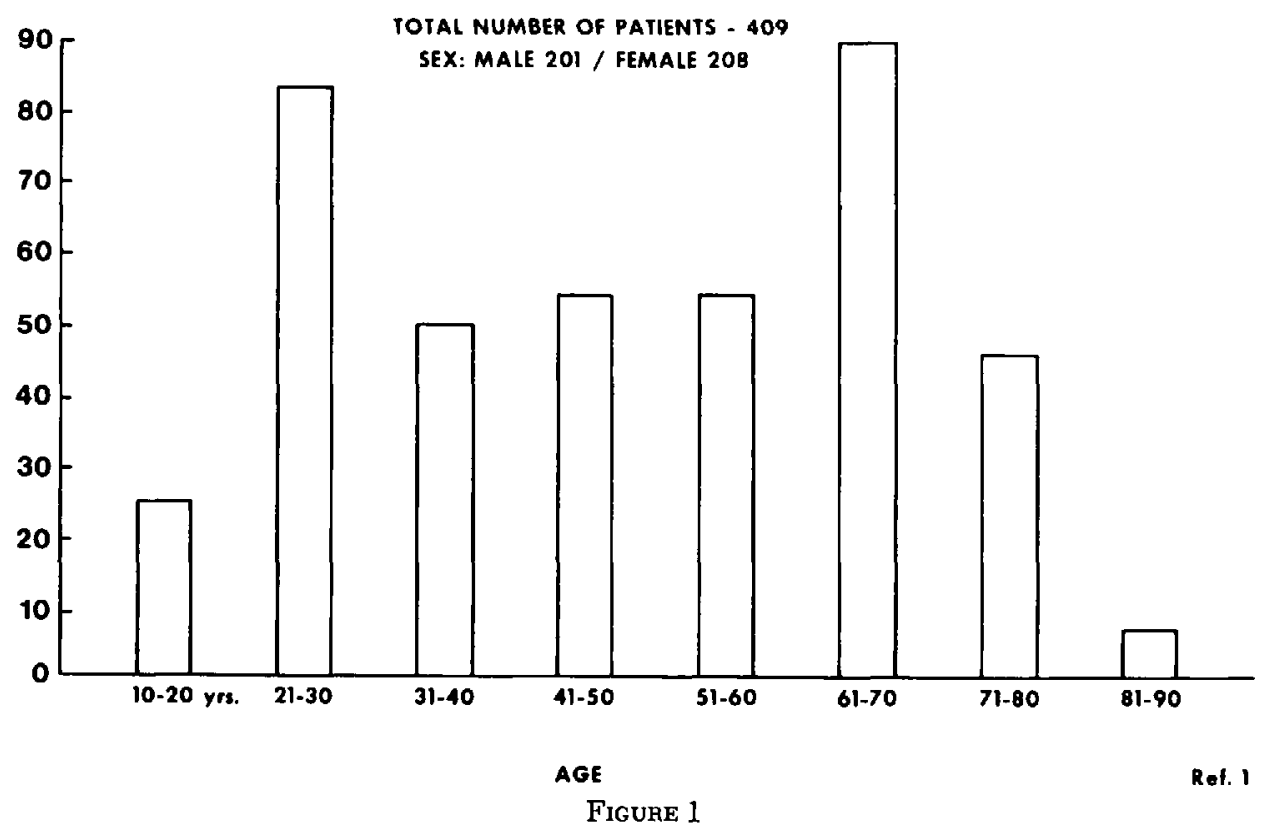

fentanyl (Sublimaze). Since we were more familiar with pentazocine it was decided to use this particular agent to achieve the desired analgesia. We were strengthened in this decision by a number of studies which have demonstrated the advantages of pentazocine. , $^{3,4}$

\section{Present Study}

Our personal experience with the new technique of Alfathesin infusion together with intermittent pentazocine now extends to 409 cases. The majority of patients were in the 21- to 30-year group ( 83 cases) and the 61- to 70-year group ( 88 cases) as shown in Figure 1. The type of operation is listed in Table I. The large majority of patients were ambulatory, which explains the age and case distribution, since most of the minor gynaecological procedures, D.\&C., breast biopsy, etc. were in the younger age group whereas cystoscopies and transurethral resection of the prostate were for the most part related to the older group of patients. Operations lasted from 15 to 20 minutes while sex distribution was approximately even with 201 males and 208 female patients.

Premedication was atropine alone or atropine together with anileridine (Leritine ), while later in the series no premedication was given.

Preparation of Maintenance Agents. The Alfathesin infusion is prepared by dissolving the contents of a $10 \mathrm{ml}$ ampoule in $120 \mathrm{ml}$ of 5 per cent dextrose in water. Ten $\mathrm{ml}$ of Alfathesin represent alphaxalone $90 \mathrm{mg}$ and alphadolone $30 \mathrm{mg}$.

To $30 \mathrm{mg}$ of pentazocine $(1 \mathrm{ml})$ is added $9 \mathrm{ml}$ of normal saline, resulting in an 0.3 per cent solution.

Method of Administration. Anaesthesia was induced by the rapid infusion over 
TABLE I

\begin{tabular}{lr}
\hline \multicolumn{1}{c}{ Procedures } & Cases \\
\hline Gynaecology & 109 \\
Cystoscopy and T.U.R. & 138 \\
T.A.B. & 58 \\
Breast biopsy & 12 \\
Urology* & \\
(excluding Cystoscopy and T.U.R.) & 58 \\
Plastic Surgery & 13 \\
Orthopedics & 6 \\
Obstetrics & 1 \\
General Surgery & 2 \\
Oral Surgery & 2 \\
E.N.T. & 4 \\
T.U.R. & 5 \\
Traumatic Surgery & 1 \\
& \\
\hline
\end{tabular}

*Urology cases were bilateral ureter transplantation, circumcision, vasectomy, hydrocelectomy, orthidopexy and fulguration of ureteral polyp.

a period of three to four minutes of Alfathesin 120 microlitres per kilogram body weight which is continued by slow infusion at 2.7 microlitres/kilogram/minute after surgical anaesthesia has become established. Analgesia was obtained with an initial injection of pentazocine 6 to $12 \mathrm{mg}$, the average being $9 \mathrm{mg}$. Further fractions of $6 \mathrm{mg}$ are repeated as indicated. In our group of patients 26.4 per cent required only the initial dose of $9 \mathrm{mg}$; 28.6 per cent received $12 \mathrm{mg}$ and 20.8 per cent needed $18 \mathrm{mg}$. The remaining patients received between $6 \mathrm{mg}$ and $120 \mathrm{mg}$.

Administration of the analgesic was discontinued before the end of anaesthesia proper and was not repeated after anaesthesia had been completed. In addition, nitrous oxide-oxygen 2 to 1 was administered to all patients in A.S.A. status 1 and in the proportion of 1 to 1 for status 2 patients. Alfathesin infusion was not used in patients with major systemic disturbances or in very poor risk patients.

Finally, if muscle relaxation was needed, succinylcholine was used in a few patients by the conventional single dose technique. Alfathesin by itself provides a certain degree of muscle relaxation, especially of the jaw, the neck and the limbs; however, this is minor in degree and muscle relaxants are obligatory when total muscle relaxation is needed. There are no significant incompatibilities between Alfathesin and succinylcholine while there is a slight potentiation with the pachycurares.

\section{Results}

In analyzing our results, the following facts emerge: the method provides adequate light anaesthesia with adequate analgesia, combined with complete and rapid recovery, superior to all other techniques. All patients were coded in the Recovery Room by the "Aldrete" method and a number of patients, selected at random, underwent psychomotor tests, such as the Newmann, Horatz and Bourdon types. Seventy-seven per cent of the patients scored a maximum of 10 points 
within 30 minutes of admission to the Recovery Room. The following figures demonstrate the superiority of the continuous infusion technique over intermittent injections: ${ }^{5}$ the incidence of apnoea with the infusion is 0.25 per cent as against 30 per cent when the intermittent administration is employed; tachycardia occurred in 0.5 per cent versus 35 per cent, hypertension in 0.5 per cent versus 25 per cent, hypotension in 1 per cent versus 25 per cent, and muscle tremors in 0.75 per cent as against 3 per cent. Furthermore only 65 per cent of patients gained maximum score in the Recovery Room within 30 minutes when they had been submitted to intermittent injection, whereas the percentage for those who had received the continuous infusion was 77 per cent. These figures would seem to indicate the superiority of the continuous infusion over intermittent injection. In our series of patients we did not encounter any cases of hypersensitivity or any histamine-like reactions. However, since the literature indicates that this possibility exists ${ }^{6-8}$ one must warn against its use in the presence of allergies. Finally, it may be worth stating that Alfathesin, although it is a steroid mixture, is not possessed of any anti-inflammatory, mineralo-corticoid, oestrogenic or progestational activities.

\section{Conclusion}

We have reported here on the technique of continuous infusion of Alfathesin supplemented by pentazocine in intermittent doses. It is proposed in future to use an infusion pump rather than an ordinary intravenous drip for this purpose, on the assumption that this will maintain an even more stable level of anaesthesia throughout the operation, as has been advocated in France by Du Cailar of Montpellier., ${ }^{9,10}$

The use of intravenous agents in the maintenance of anaesthesia has many advocates ${ }^{12-14}$ and it would seem that a technique of continuous infusion with Alfathesin quite significantly reduces some common side effects of intravenous anaesthesia. It is not the purpose of this paper to discuss in detail the advantages of intravenous over inhalation anaesthesia but it is obvious that it represents a further step in the control of operating room pollution. Hence any improvement in intravenous anaesthesia must be welcome if for no other reason than that of an improved ecology in the operating room.

\section{RÉSUMÉ}

Nous venons de vous présenter notre expérience personnelle et les résultats obtenus avec l'Alfatésine en perfusion en association avec la Pentazocine à doses répétées et fractionnées. Nous prévoyons pour l'avenir non seulement l'emploi d'Alfatésin en perfusion mais également son utilisation avec une pompe à débit constant. A l'heure actuelle, cette méthode est déjà préconisée en France par le Professeur Du Cailar de Montpellier, et elle fait l'objet de publications intéressantes dans les annales de l'anesthésiologie française. L'utilisation en anesthésie intraveineuse d'un débit constant possède l'avantage de maintenir en état encore plus stable, que lors d'une simple perfusion, les différents éléments de l'anesthésie et ceci du commencement à la fin de l'intervention. De plus, l'Alfatésine est une drogue qui n'est pas l'objet de fixation sur les protéines, qui a par conséquent une vie courte et qui nécessairement n'a pas d'effet cumulatif. Elle répond donc à la 
fois aux critères d'administration par perfusion ou par débit constant. D'ailleurs, le Professeur Du Cailar a mème réalisé un film à ce sujet qu'il a d’ailleurs présenté en primeur lors du dernier congrès de la francophonie anesthésique au Québec en fin d'avril.

En résumé, la présente communication nous a fait voir très clairement les nombreux aspects de l'anesthésie intraveineuse en perfusion et démontre sans aucun doute son aptitude à réduire de façon très significative les effets secondaires habituels attribuables à l'anesthésie intraveineuse. De plus, le but de ce travail n'est certes pas de discuter en détail les avantages de l'anesthésie intraveineuse en comparaison avec ceux de l'anesthésie par inhalation. Cependant, à la suite des travaux de Cohen, et al., "Anesthesia, Pregnancy and Miscarriage", de Knill-Jones, et al., "Anesthetic Practice and Pregnancy", et de l'Etude Nationale Américaine, sur le sujet, dans le monde anesthésiologique, l'écologie du bloc opératoire est de plus en plus un sujet d'étude à l'ordre du jour. Enfin, la mise au point de nouvelles techniques d'anesthésie intraveineuse de plus en plus perfectionnées, comme celle que nous venons de rapporter par exemple, marquera peut-être un jour un pas do plus vers la solution idéale des problèmes de pollution pour le personnel du bloc opératoire.

\section{REFERENCES}

1. Child, K.J., Harnby, G., Gibson, W., \& Hart, J.W. Metabolism and excretion of althesin (CT 1341) in the rat. Postgraduate Medical Journal: Steroid Anaesthesia, Supplement 2, 48: $37-43$ (1972).

2. Du Cailar, J., Lefebvre, F, Kienlen, J., \& Moreau-Petitdidier, M. Effets chez l'homme d'une perfusion d'un nouvel agent anesthésique steroidien: le CT 1341 (Althesin), avec étude particulière des effets cardiovasculaires. Annales de l'Anesthésiologie Française, pp. 33-45 (Fevrier-Mars 1972).

3. Rifat, K. Pentazocine in sequential analgesic anaesthesia, Brit. Jour. Anaes. 44: 175-181 (1972).

4. Poisvert, M., Debras, C., Galinski, R., et Millet, D. Notre expérience de l'utilisation de la Pentazocine en association pour l'anesthésie prolongée, l'anesthésie brève et l'anesthésie chez l'adulte et l'enfant. Annales de l'Anesthésiologie Française, 10: 613-616 (1969).

5. Dechêne, Jean-Paul Alphathesin, a new steroid anaesthetic agent. Cdn. Anaes. Soc. Jour. 23: 163-168 (1976).

6. Clarke, R.S.J., Dundee, J.W., Garrett, R.T., McArdle, G.K., \& Sutton, J.A. Adverse reactions to intravenous anaesthetics: a survey of 100 reports. Brit. Jour. Anaes. 47: 575-585 (1975).

7. Ohresser, P. Alfatésine et réactions allergiques. Annales de l'anesthésiologie française, 15: 35-37 (1974)

8. WATT, J.M. Anaphylactic reactions after use of CT 1341 (Althesin). Brit. Med. Jour. 3: 205-206 (1975).

9. Du Cailar, J., Evrard, O., Pecuret, C., \& Deschodt, J. Anesthésie à l'Alfathésine par perfusion à la seringue automatique à débit constant. Annales de l'anesthésiologie française, 15: 661-668 (1974).

10. Du Cailar, J., Deschodt, J., Bessou, D., et Cabanel, Ph. Anesthésie à débit constant par l'association Alfathésine-Fentanyl. Annales de l'anesthésiologie Française, 16: 331$340(1975)$.

11. Cohen, E.N., Weldon, Belleville J., \& Brown, B.W., Jr. Anesthesia, pregnancy, and miscarriage: a study of operating room nurses and anaesthetists. Anesthesiology 35: 343-347 (1971).

12. Knill-Jones, R.P., Moir, D.D., Roderigues, L.V., \& Spence, A.A. Anaesthetic Practice and Pregnancy. Lancet, pp. 1326-1328 (June 17, 1972).

13. Report of an ad hoc committee on the effect of trace anesthetics on the health of operating room personnel. American Society of Anesthesiologists, occupational disease among operating room personnel: a national study. Anesthesiology 41; 321-337 (1974). 